\title{
Health centres and labs left reeling by Katrina
}

In the aftermath of last week's hurricane, scientists from research facilities and medical centres in the area are counting the cost - to patients, buildings and their research.

Hardest hit are three medical facilities Charity Hospital, and the health science centres at Tulane University and Louisiana State University (LSU), all of which are located close together in downtown New Orleans.

At the Tulane centre, Paul Whelton, physician and senior vice-president for health sciences, says that for four desperate days after the waters rose, patients were kept alive with hand-pumped ventilators. Surgeons swam through dirty flood waters to reach nearby hospitals, he adds, while faculty scientists kept freezers functioning and some 5,000 research rodents alive on the slimmest of supplies.

"It was truly heroic," says Whelton, who was evacuated along with the last of the staff and patients on 2 September. "I couldn't be more proud of the faculty, staff and administration."

The nearly 13,000 undergraduate students at Tulane evacuated their campus before the hurricane hit on 29 August, but the science staff stayed behind to look after patients and research facilities. Despite the loss of power when the auxiliary generators ran out of fuel, no staff or patients were lost, says Whelton, and about 250 patients were flown out by helicopters provided by the Hospital Corporation of America, which manages the facility, before military helicopters arrived.

At nearby Charity Hospital, which cares for New Orleans' poorest, the situation was grimmer. "It was bad," says Whelton. "They had dead laying in the stairwells." About 30 critically ill patients were moved in small boats to Tulane to be flown out. "Faculty and nurses rowed them over. Some were on portable respirators. Staff worked in shifts hand-pumping air to them," Whelton says.

Whelton had no information about LSU's Health Science Center, situated a few blocks away, although Norka Ruiz Bravo, the National Institutes of Health's deputy director for extramural research, says he finally heard from officials there on 4 September. Attempts are being made to move some of the centre's core research specimens to facilities in Baton Rouge or Pennington.
IMAGE

UNAVAILABLE FOR COPYRIGHT REASONS

Patients evacuated by helicopter get treatment at Louisiana State University in Baton Rouge.

Before the last staff left the Tulane facility, they topped up nitrogen tanks to keep their cell lines, bacterial cultures and other specimens frozen. But some research animals are likely to have been lost. As Nature went to press, Tulane personnel were planning to return by truck through the 1-2 metres of water that still surrounds the hospital, to do a damage assessment and try to rescue irreplaceable cell lines, such as those from the stem-cell and gene-therapy facilities. ${ }^{\alpha}$ We are hoping for the best, but fearing for the worst," says Whelton.

Facilities elsewhere escaped more lightly. The Stennis Space Center in Mississippi lost the roof from its administration building, and other buildings were damaged by water. ${ }^{\alpha}$ The good news is there were no staff fatalities or injuries," says NASA spokesman David Steitz. "But it looks like most of the workforce lost their homes."

NASA's Michoud Assembly Facility, in the coastal lowlands east of New Orleans, could only be reached by helicopter or boat for several days after the storm. The space shuttle's external fuel tanks are made there, but preliminary indications are that the tanks were not damaged, although damage to the buildings could still delay future flights.

Meanwhile, the Laser Interferometer Gravitational Wave Observatory at Livingston, and the Tulane National Primate Research Center, north of New Orleans, did not suffer significant damage. Conferences due to be held in New Orleans' convention centre have been cancelled, at least up to December.

Rex Dalton 